\title{
Începuturile lexicografiei maghiare. De la primele glose pînă la dicționare multilingve
}

\author{
Emese Fazakas* \\ Facultatea de Litere, Universitatea „Babeș-Bolyai,, Str. Horea 31, 400202 Cluj-Napoca, România
}

\section{Despre articol \\ Istoric:}

Primit 15 septembrie 2021

Acceptat 5 octombrie 2021

Publicat 12 decembrie 2021

Cuvinte-cheie:

lexicografie

glose

nomenclatura

vocabularium

dicționar

\begin{abstract}
Rezumat
Articolul de faţă are ca scop prezentarea începuturilor lexicografiei maghiare, mai ales a acelor lucrări care au o strînsă legătură cu Transilvania. Glosele timpurii, începînd din secolul al 13-lea, sînt fie marginale, fie interliniare. Singura sursă timpurie în care glosele sînt intertextuale, distinse de textul latin prin subliniere, este Sermones Dominicales, o compilație de predici scrise în prima parte a secolului al 15-lea. Vocabularele și nomenclaturile discutate sînt redactate între secolul al 14-lea și sfîrșitul secolului al 16-lea, majoritatea avînd la bază o listă de cuvinte latine grupate în cîmpuri semantice. Singura lucrare care s-a redactat pornind de la lexicul maghiar este Nomenclatura din Schlägl, o copie făcută în jurul anului 1405 după un document întocmit cu cîteva decenii mai devreme. Printre aceste vocabulare găsim și cîteva care pot fi considerate primele încercări de redactare a unor dicționare de specialitate. Începînd cu secolul al 16-lea apar mai multe dicționare ale căror cuvinte-titlu sînt aranjate alfabetic, însă cele timpurii au rămas nefinalizate ori nu s-au păstrat în întregime. Cele mai reprezentative dicționare, majoritatea multilingve, se redactează începînd cu sfîrșitul secolului al 16-lea. Prezentarea se încheie cu dicționarele botanice ale lui József Benkő, editate în 1783, care marchează începutul lexicografiei moderne maghiare.
\end{abstract}

\section{Introducere}

Scopul articolului de față este de a prezenta primele încercări de întocmire a unor vocabulare, dicționare biși multilingve, surse indispensabile în cercetarea dezvoltării lexicografiei și în analiza diacronică a lexicului. De asemenea, sînt prezentate și glosele, ele fiind cele mai vechi încercări de acest fel, deși scopul lor primar era înțelegerea unui anumit text întocmit într-o limbă străină. Pe lîngă aceste glose-care s-au scris chiar și în secolul al 16-lea-începînd din secolul al 14-lea avem deja vocabulare, nomenclatoare bilingve, dintre care le vom prezenta pe cele mai importante. Putem spune că lexicografia maghiară modernă se naște cu acele dicționare-mai ales multilingve-care s-au redactat de la a doua jumătate a secolului al 16lea. Sfîrșitul secolului al 18-lea poate fi considerat un prag în lexicografia maghiară, deoarece anul 1772 marchează începutul unei perioade în care reforma limbii era prioritară pentru erudiții maghiari. Astfel, începînd cu primele decenii ale secolului al 19-lea s-au redactat zeci de dicţionare. Prezentarea se limitează numai la lucrările lexicografice bi- și multilingve, dicționarele explicative nefiind incluse.

\section{Dezvoltarea lexicografiei maghiare}

În lumina surselor lingvistice descoperite, putem spune că lucrările cu caracter lexicografic apar aproape concomitent cu primele texte bisericești. Avînd scopuri practice, fie de a înțelege un text, fie de a învăța și a preda o limbă străină, treptat apar și acele lucrări care pot fi numite vocabulare, iar apoi dicționare, aşa cum le cunoaștem în zilele noastre. Voi prezenta cele mai semnificative lucrări apărute între secolul al 13lea și al 18-lea, care au contribuit la dezvoltarea lexicografiei maghiare. Deși din punct de vedere temporal

*Adresă de corespondență: fazakasemese@gmail.com. 
grupele de mai jos se suprapun, am optat pentru o grupare pe baza caracteristicilor lucrărilor și nu pentru cea cronologică, deoarece în acest fel se pot vedea progresele cărturarilor. Astfel, primele lucrări reprezintă glosele, apoi voi prezenta vocabularele și nomenclatoarele manuscrise și tipărite, iar la sfirș̦it dicționarele ordonate alfabetic.

\subsection{Glose}

Fiind surse importante ale cercetării lexicologice și lexicografice-și constituind primele încercări de a reda echivalentele unor cuvinte sau ale unor expresii latine în limbile vernaculare-, nu putem omite prezentarea cîtorva dintre glosele timpurii. Acestea erau scrise-ca de altfel în Europa Evului Mediuori cu scopuri pedagogice, ori cu scopul de a înțelege mai bine textele scrise într-o altă limbă, în cazul nostru în latină.

Primele glose cunoscute, care cuprind 11 cuvinte maghiare, numite Glosele din Oxford, au fost introduse într-un codice latin în jurul anului 1230. Codicele scris de Petrus Comester, avînd titlul Historie Scholastice, a fost întocmit cu scopul învăţării și al interpretării textelor biblice și era folosit în educarea studenților din școlile episcopale. Glosele marginale descoperite de către arhivistul Bibliotecii Centrale a Universității din Oxford, Albinia de la Mare, au fost prezentate și analizate în detaliu de Mezey (1979, 1981), apoi completate cu alte explicații de Büky (1984) și Benkő (1984). Glosele maghiare se referă la niște obiecte sau plante care se foloseau și se găseau în Regatul Maghiar. De exemplu: „C rix-cis [!] est herba que in acquis crescit et manum incidit, quod dicitur in hungaria sas”, „id est quibusdam spericis retinnaculis quibus ora uestium constringi solent, quod in hungarico dicitur güb [gumb]" (Mezey, 1981).

Pe la sfîrşitul secolului al 13-lea, în jurul anului 1290, un erudit maghiar menționează 4 verbe conjugate într-o compilație de predici scrisă la Paris. Glosele s-au păstrat într-un codice aflat la biblioteca Vaticanului; astfel, acestea au primit denumirea de Glosele de la Vatican (Gábriel, 1943).

Glosele din Alba Iulia au fost scrise în primele decenii ale secolului al 14-lea (în jurul anului 1320) și se află la Biblioteca Batthyaneum (R.III. 89, f. 50 $0^{\mathrm{r}}, 125^{\mathrm{r}}, 154^{\mathrm{r}}$ ). Codicele descoperit de Elemér Varjú în 1898 (vezi Varjú, 1899) conține 3 rînduri rimate în limba maghiară pe marginea unor predici latine, scrise cel mai probabil de franciscani (Madas, 2009, p. 228-229).

Unul dintre cele mai renumite manuscrise vechi maghiare aflate azi la Biblioteca Teleki-Bolyai din Tîrgu-Mureș este codicele Koncz. Cartea latină scrisă pe foi de pergament în secolul al 14-lea a fost descoperită de bibliotecarul Colegiului Reformat din Tîrgu-Mureș, József Koncz, în a doua parte a secolului al 19-lea, într-o clădire anexă aflată în proprietatea familiei Rhédey din Sîngeorgiu de Pădure. Bibliotecarul a transportat codicele la Biblioteca Colegiului, iar în 1948 patrimoniul bibliotecii a fost preluat de Biblioteca Teleki-Bolyai, unde Elek Farczády și Attila Szabó T. au identificat niște rînduri și cîteva glose scrise în limba maghiară (vezi Farczády \& Szabó T., 1957; Szabó T., 1957; Benkő, 1958). Aceste rînduri coerente de cîteva linii și 11 glose marginale (denumite Rîndurile și Glosele de la Tg-Mureş) au fost redactate la începutul secolului al 15-lea. Textul este sinteza unor fragmente ale Cărții Regilor din Vechiul Testament și conține în total 55 cuvinte în maghiară.

Din a doua jumătate a secolului al 15-lea avem o culegere de 123 de predici scrise de un erudit maghiar, manuscris aflat la Biblioteca Universității ELTE din Budapesta (Cod.Lat. 98). Autorul codicelui denumit Sermones Dominicales avea intenția de a ajuta clericii în alcătuirea unor predici pentru credincioșii maghiari, inserînd în textele latine numeroase cuvinte și expresii în limba maghiară. Aceste înscrieri pot fi grupate în două categorii: glose interlineare în cazul pericopelor și glose intertextuale în predici scrise de aceeași mînă, după corespondentele lor latine și distinse de textul latin prin subliniere. Acestea din urmă sînt traducerile unor expresii, cuvinte latine puțin cunoscute sau considerate a fi mai grele (de exemplu, f. $230^{\text {va }}$ : „consubstantialis - állatban egy”; f. 130 ${ }^{\mathrm{rb}}$ : „naturalis - természet szerint való, essentialis - állat szerinti”) sau denotă sentimente puternice (de exemplu, strigătele Fecioarei Maria $131^{\mathrm{rb}}$ : ,jaj nekem” 'vai de mine’, „Én egyetlen egy szerelmem” 'Singura mea iubire’1) (Tóth, 2009a, p. 244-245). Din punct de

${ }^{1}$ Exemplele sînt redate cu ortografia contemporană, așa cum apar în Tóth (2009a). În continuare exemplele sînt scrise așa cum apar în manuscrise sau în ediții. 
vedere dialectal, glosatorul este din regiunea sud-estică a Regatului Maghiar (azi județul Baranya) (vezi Mészöly, 1910; Zolnai, 1910; Tóth, 2009a).

Din secolul al 16-lea avem mai multe glose cu tematică comună: denumirile unor plante, dar și denumirile unor animale și minerale. Glosele Casanate de la începutul secolului al 16-lea, descoperite în Biblioteca Casanate din Roma se găsesc într-un lexicon medical cu intrări ordonate alfabetic și cu numeroase ilustrații. Majoritatea cuvintelor-titlu denumesc plante, animale și minerale, iar explicaţiile se referă la folosirea lor în medicină. Glosele maghiare se află în partea superioară a 87 de ilustrații ale plantelor medicinale. Pe lîngă acestea apar și 7 cuvinte maghiare pe marginea unor rețete medicale. Glosele au mai mulți autori: primul a adăugat 44 de denumiri în prima parte a secolului al 16-lea, al doilea este autorul a 33 de cuvinte la sfîrșitul aceluiași secol, iar celelalte au fost adăugate de 4 sau 5 autori la începutul secolului următor (Schönherr, 1904).

În ediția din 1517 a primei lucrări enciclopedice de științe naturale—Ortus Sanitatis—au fost inserate 454 denumiri de plante, animale și minerale în limba maghiară, între anii 1520-1530. După cum constată Ernyey \& Jakubovich (1915), glosatorul ar fi fost medic.

Alte două cărți în care avem sute de glose maghiare au fost prezentate și analizate de Szabó T. (1943, 1958). Prima este o carte de științe naturale, scrisă în latină, avînd titlul De herbis et simplicibus medicamentis. Deoarece lipsește coperta și pagina titlu, nu știm exact despre care ediție este vorba. Glosele înscrise pe la sfîrșitul secolului al 16-lea sînt în număr de 400 și se referă numai la plante medicinale. Cartea, al cărei ultim proprietar era un profesor medic al Colegiului Reformat din Cluj între anii 1758 și 1784, Sámuel Pataki, are mai multe glose maghiare introduse în secolele al 17-lea și al 18-lea, chiar și de către susnumitul pedagog. Cealaltă carte, editată la Marburg în 1543, este o ediție a operei lui Discorides De Medicinali Materia Libri Sex îmbogățită cu nume de plante, medicamente și animale în limbile greacă, latină, ebraică și germană de către Ioannes Lonicerus. În acest exemplar-care se află la Biblioteca Filialei din Cluj a Academiei Române - au fost introduse 50 de nume de plante maghiare pe la sfirșitul secolului al 16-lea. Și această carte are mai multe însemnări maghiare din secolele al 17-lea și al 18-lea. Glosatorii nu au putut fi identificați, după cum precizează Szabó T. (1958).

Glosele din Cluj sînt prezente într-un dicționar latin-german editat în 1528. Aproape toate paginile dicționarului au însemnări în maghiară. O parte a gloselor, aproximativ 800 de cuvinte, datează din jurul anului 1550, iar celălalt grup (aproximativ 3300 de cuvinte) a fost introdus prin anul 1577 de mai multe persoane care au făcut și corecturi în inscripțiile precedente. Prima mînă aparține unei persoane din regiunea vestică a Regatului Maghiar, iar corecturile și însemnările ulterioare sînt făcute de o persoană sau mai multe originare din zona Trei Scaune (regiunea Covasnei) (Pálfi, 1907).

Glosele din Turda aparțin unui tînăr, Tamás Tordai, născut la Turda în 1551. Elev fiind la Cluj, a introdus mai multe denumiri de obiecte, noțiuni, verbe și substantive abstracte maghiare legate de viața cotidiană a țăranilor în cartea intitulată Cornucopie a lui Perottus (ediția 1532, Basel) între anii 1568 și 1573. Pe spatele coperții găsim și o listă de cuvinte latine cu corespondentele lor maghiare, însă această listă aparține unei alte persoane, care nu a putut fi identificată. După anul 1616, cartea ajunge în posesia lui Benedek Nagyrákosi, care, la rîndul lui, glosează mai multe sute de expresii, cuvinte latine cu lexeme maghiare (Viski, 1906).

\subsection{Vocabularia, nomenclatura}

Avînd scop pedagogic, primele vocabularia și nomenclatura nu sînt structurate alfabetic, ci cuvintele sînt grupate tematic și conțin mai ales substantive. Primele vocabularia și nomenclatura sînt desigur manuscrise, primul lexicon tipărit, ordonat tematic, datînd din 1533.

Cele care ne interesează în mod deosebit apar la sfîrșitul secolului al 14-lea (Nomenclatura din Königsberg, Nomenclatura din Bistrița și Nomenclatura din Schlägl) și par să aibă aceeași sursă: un vocabular latin-german ${ }^{2}$ (Vízkelety, 2009). Nomenclatura din Königsberg, scrisă între 1350 și 1380, are 159 cuvinte latine și 100 de echivalente maghiare. Acestea denumesc grade de rudenie, cele cinci simțuri, calități fizice

\footnotetext{
${ }^{2}$ De fapt în dialect bavarez.
} 
și mentale, adjectivele legate de aceste calități, substantive denumind boli, haine, unelte, arme etc. (Melich, 1916). Textul original al Nomenclaturii din Bistrița a fost redactat între anii 1380 și 1390 pe baza aceluiași vocabular latin-german, iar cele 15 foi care au fost descoperite la sfirșitul secolului al 19-lea sînt copii făcute în jurul anului 1395-sau între anii 1380 și 1410—de către o singură mînă (Gáldi, 1938) ${ }^{3}$. Autorul este "Georgius de regno dicto Sclavonije”, deci era originar din sud-vestul Regatului Maghiar. Vocabularul este structurat pe 21 de cîmpuri semantice și conține 1316 cuvinte maghiare ${ }^{4}$.

Avînd aceeaşi sursă, Nomenclatura din Schlägl este tot o copie făcută în jurul anului 1405 după un document întocmit cu cîteva decenii mai devreme. Acest vocabular are o însemnătate deosebită, deoarece este prima încercare de a redacta o nomenclatură pornind de la lexicul maghiar, și nu de la cel latin. Cuprinde 2140 cuvinte maghiare aranjate în 32 de cîmpuri semantice ${ }^{5}$. Acest nomenclator este legat de un dicționar explicativ latin cu intrări ordonate alfabetic, cu titlul Hortularium (Prämonstratenser Stiftbibliothek, Cpl 156), scris între anii 1420 și 1433 (vezi mai jos, \$2.3.2).

Pe paginile albe ale unei cărți editate în anul 1516 și care a făcut parte din patrimoniul Bibliotecii Colegiului Reformat din Cluj la vremea descoperirii sale au fost introduse 75 de nume de plante latine și corespondentele lor în maghiară. Totalul cuvintelor maghiare este de 118. Aceste pagini scrise în jurul anului 1520 reprezintă prima încercare cunoscută nouă de a întocmi un vocabular botanic (Viski, 1905).

Lexiconul latin-german, anexa tematică a unui manual scris de umanistul german Ioannes Murmellius, a avut mai multe ediții, iar cea care este importantă din punctul nostru de vedere este ediția din 1526, apărută la Cracovia. Această ediție a fost folosită de un erudit maghiar pentru a crea un lexicon latingerman-maghiar: Lexicon Joannis Mvrmellii, in qvo Latina rerum uocabula in suas singula digesta classes, cum Germanica et Hungarica interpretatione Vt autem quodquis uocabulum facile inueniatur prestabit Index copiosus (Cracovia 1533). Găsit la mănăstirea franciscană din Schwaz, lexiconul cuprinde mai ales substantive grupate în cîmpuri semantice ${ }^{6}$. Numărul intrărilor maghiare este de aproximativ 4600 de cuvinte, iar autorul uneori dă și explicații, de exemplu: „Anisum - Oly fy ki embernek io szint ad” 'iarbă ce dă culoare (sănătoasă) feței' (1453), „Cicercula - Tatárka ninczen magyar orsakban” 'hrișcă nu există în Ungaria' (1540), „Cereuisia saxonica - Saxoniabeli sŏr magyarnak nehez es segen ital” 'bere din Saxonia, băutură grea și săracă pentru maghiari' (2180) (Szamota, 1896).

Gábor Pesti (? Pest, 1542 - 1550) este autorul unei nomenclaturi care a avut șase ediții: Nomenclatura Sex Lingvarvm Latine, Italice, Gallice, Bohemice, Hungarica, Germanica nouiter accessit... Per Gabrielem Pannonium Pesthinum (Viena 1538, 1550, 1561, 1568). Nu este o lucrare originală în întregime, baza fiind un dicționar latin-italian-francez-ceh-german editat în 1531 la Nürnberg (Vocabularius utilissimus quinque linguarum), folosit mai ales în școlile germane și cehe. Pesti redactează dicționarul pentru studiu individual (vezi și ediția reprint 2013 de Editura Tinta din Budapesta). Autorul lucrează pe baza cuvintelor latine, chiar face corecturi în textul latin. În prima parte a cărții găsim cuvinte grupate în 55 cîmpuri semantice, cele nouă subcapitole ale părții a doua includ verbe, fraze de uz cotidian pentru cei care vor să se facă înțeleși în maghiară și care vor să poarte conversații despre călătorii, călărie, solii (Gl.).

Fabricius Balázs Szikszai (c. 1530, Szikszó - 1576, Sárospatak ${ }^{7}$ ) scrie un nomenclator tematic cu scop pedagogic între anii 1561 și 1574, pe vremea cînd era profesor la Colegiul din Sárospatak: Nomenclatura sev Dictionarium Latino-Vngaricum perclarissimom D. Basilium Fabricium Szikszauianum. Szikszai a avut ca model opera lui Murmellius, pe care a îmbogățit-o; astfel, nomenclatura cuprinde 9550 de cuvinte

\footnotetext{
${ }^{3}$ Finály (1892), făcînd o analiză amănunțită, ajunge la concluzia că manuscrisul s-a redactat la finele secolului al 14-lea și afirmă că această copie s-ar fi scris la începutul secolului al 15-lea.

${ }^{4}$ Exemple: „humus - agag; collis - halm; colliculus - kis halom; kauerna - liuk; rus - mezeu; campus - idem”.

${ }^{5}$ Iată cîteva exemple din grupa a 12-a, care conține denumiri ale speciilor de pești: „hal PIfcis - halaftho pifcina - kis hal pifcic ulus - toc dorica - viza vfo - harcha barbota - chompo tuica[?] - hal fereg 'sőreg' phin fturio - pofar pofardus - idem porand[us] - idem ftarpo - verian capito - chuca luceus - idem lumb[us]” (Zelliger, 2009, p. 237; vezi și Szamota, 1894).

${ }^{6}$ De exemplu: „De deo et rebus coelestibus - Istenrŏl es eghi dolgogrol - De temporibus - Ewdǒkrŏl - Terræ, Aquarum, et locorum uocabula Feldnek: visseknek es helŭknek neuek - De uarijs morborum generibus - Kulem fele betegsegrŏl - De piscibus - Hallakrol - De libris - Kŏnuegrŏl” (Szamota, 1896).

${ }^{7}$ Ambele localități se află astăzi în județul Borsod-Abaúj-Zemplén, Ungaria.
} 
maghiare grupate în 113 cîmpuri semantice. Prima ediție a dicționarului, editat pe baza copiilor făcute de elevi, a apărut la Debrecen în 1590, după trecerea în neființă a autorului (Melich, 1907). Colegiul din Sárospatak avînd o vie, o livadă și o grădină proprie, Szikszai a introdus foarte multe noțiuni legate de viticultură, pomicultură, grădinărit. Astfel, opera lui este o sursă foarte bogată pentru cei care studiază lexicul istoric al viticulturii și al grădinăritului, în general al botanicii (Gombocz, 1936). Ediţia 1602 a fost îmbogățită cu echivalente germane ale cărui autor nu ne este cunoscut, însă se poate afirma că era de etnie săsească din regiunea Transilvaniei. Această ediție trilingvă s-a folosit în cele mai multe școli pînă în anul 1644 și a fost reeditată în 1629 la Sibiu de Marcus Pistorium: Nomenclatura seu dictionarivm LatinoGermanicum, ex varijs probatisque Autoribus collecta. Nunc denvo adiectum idioma Hungaricum, in usum discentium. Deși în titlu apare expresia „autoribus collecta”, această carte este retipărirea nomenclaturii lui Szikszai, ediția 1602 (Melich, 1906, p. 428-429) $)^{8}$.

Prima încercare de a alcătui un vocabular de termeni juridici latin-maghiar este acel Index verborum Latino-Hungaricus care a fost tipărit în 1611 ca o anexă la cea mai importantă lucrare juridică a secolului al 16-lea: Werböczy István Decretvm Juris consuetudinarij, Inclyti Regni Hungarie et Transylvanie, azaz Magyar és Erdélyország törvénykönyve, Verböczi István által iratott 1514. eszten. Mostan Deakul es Magyarul, Egy hasznos Regestromal egyetemben uyobban ki boczatatot cum gratia et privilegio ${ }^{9}$. Din a doua jumătate a secolului al 15-lea cunoaștem o carte de expresii și fraze juridice scrisă de un notar public, pe nume de János Magyi, care a adăugat glose maghiare (în total 143 cuvinte) lîngă sintagmele, frazele specifice documentelor juridice latine (Kertész, 2009), însă opera tipărită în 1611 este prima lucrare lexicografică de acest fel.

\subsection{Dicționare organizate alfabetic}

Primele dicționare ordonate alfabetic apar în secolul al 15-lea. Printre acestea pentru două s-au găsit doar fragmente, iar unul (cel din Braşov) poate fi considerat mai mult un glosar ${ }^{10}$, însă, fiind scris pe teritoriul Transilvaniei, are o însemnătate aparte pentru noi. Aceste fragmente de dicționar și primul dicționar bilingv complet sînt manuscrise. Primul dicționar tipărit este multilingv, iar printre marile și importantele lucrări lexicografice se află acele dicţionare care au cunoscut mai multe ediții, s-au folosit timp îndelungat și au avut o influență asupra dezvoltării lexicografiei maghiare moderne.

\subsubsection{Dicționare organizate alfabetic incomplete}

Primul este Dicționarul din Gyöngyös (județul Heves, Ungaria), redactat între anii 1525 și 1556. Originalul s-a pierdut, însă copia făcută în jurul anului 1560 a fost găsită legată de un exemplar al cărții Catholicon de Balbus de Ianua (1487, Veneția). Copiatorul avea intenția de a continua, deoarece ultimele două pagini albe sînt și ele liniate (Melich, 1898) și cel mai probabil copiase dintr-o lucrare finalizată. Manuscrisul are 39 pagini și conține 4617 cuvinte-titlu latine cu 10400 corespondente maghiare. Ultimul cuvînt latin este cilones. Este, de fapt, un dicționar explicativ al limbii latine ${ }^{11}$, cu mențiunea posibilei etimologii și exemple din autori latini antici, la care nu numai s-au adăugat echivalentele maghiare, ci uneori s-au tradus și explicațiile ${ }^{12}$. De asemenea, autorul maghiar de multe ori folosește și sinonime sau explicații: „Alutarius - szyw gyarto vel tymar; Carnificina: pelenger pyach: nyluan valo hely: holoth az hoharoktol Emberek olettethnek" (Melich, 1898). Aceste sinonime și explicații dovedesc că autorul era conștient de

\footnotetext{
${ }^{8}$ Tot la Sibiu apare în 1709 un vocabularium triling (Vocabularium trilingve. Pro Usu Schole Cibiniensis recusum. Cibinii, Typis Reichardianis. Per Michaelem Hetzdörffer) care are la bază aceași ediție, iar regionalismele arată că eruditul maghiar care a contribuit la scrierea vocabularului era originar din zona Trei Scaune (Covasna). (Vezi și Fejér, 1995).

${ }^{9}$ Este de menționat că prima traducere parțială a lucrării lui Werbőczy datează din 1565 și a fost făcută de Balázs Weres, notarul public (notarius publicus) din comitatul Bihor (Péter, 2012), iar limba legislației în Translvania după 1541, pe durata Principatului, era limba maghiară.

${ }^{10}$ Deși eu consider că această lucrare ar fi un glosar, literatura de specialitate o numește dicționar (Brassói szótártöredék).

${ }^{11}$ Explicațiile latine nu sint numai din Catholicon, ci din mai multe dicționare latine scrise în Italia, din Vocabularium al lui Papias, Dictionarium de Calepinus (una dintre edițiile înainte de 1544) (Melich, 1898).

${ }^{12}$ De exemplu: „Ascarotum, pauimentum picture arte elaboratum, sic dictum: quod uerri non debeat, i. purgari. Mesterseggel alkottatott: megh yrth pagymontom”.
} 
faptul că, alegînd doar un corespondent într-o altă limbă, nu întotdeauna putem reda înțelesul cuvîntului străin.

În jurul anului 1580, un erudit maghiar, inspirat de edițiile operei lui Calepinus, scrie un dicționar ${ }^{13}$. Din păcate, lucrarea s-a pierdut, s-au găsit numai două fragmente: cuvintele cuprinse între én 'eu' și erö 'putere' (Nagy, 1887). Noutatea lucrării nu o reprezintă numai intrările ordonate alfabetic, ci și faptul că este fragmentul unui dicționar maghiar-latin, adică autorul trebuia inițial să facă o listă a cuvintelor limbii lui materne și să o aranjeze alfabetic, neavînd model. Cele 200 de cuvinte-titlu maghiare au nu numai corespondente latine, ci și explicații, iar uneori autorul include și sintagme (Bartók, 2017), exemplificînd aria de folosință a cuvintului respectiv, ca în lucrările lexicografice moderne ${ }^{14}$. Uneori oferă explicații și în limba maghiară: „Ep kybe semmy fogiatkozas ninch. Syncerus. syncere, et synceriter unde synceritas. Quasi sine carie, pro puro incorrupto immaculate contrarium” (Bartók, 2017, p. 32).

Fragmentul din Braşov constă de fapt din glose maghiare înscrise într-un dicționar explicativ-etimologic latin, aranjat alfabetic, avînd ca model lucrarea Catholicon de Balbus de Ianua. Corespondentele maghiare (în număr de aproximativ 200) au fost introduse lîngă cele latine de către două persoane. Cele mai multe intrări s-au făcut între 1580 și 1590, o parte însă puțin mai tîrziu, la începutul secolului al 17-lea. Melich (1905) — după o analiză detailată—constată că glosatorii erau originari din zona Ciucului și a comitatului Trei Scaune, unul dintre autori putînd fi localizat deoarece în jurul anului 1617 a adăugat și nişte însemnări personale pe margine ${ }^{15}$.

\subsubsection{Dicționare organizate alfabetic din secolele al 15-lea - al 18-lea}

Primul nomenclator care pornește de la lexicul maghiar, Nomenclatura din Schlägl, a fost descoperit legat de un dicţionar explicativ latin cu intrări ordonate alfabetic, cu titlul Hortularium (Prämonstratenser Stiftbibliothek, Cpl 156), scris între anii 1420 și 1433. Echivalentele maghiare din Hortularium nu sînt glose, nu au fost introduse ulterior în dicționar, ci scrise în continuarea cuvintelor latine de aceeași persoană, deci este prima lucrare lexicografică „modernă”. Din punct de vedere dialectal, persoana care a redactat dicționarul cel mai probabil era originară din partea nord-vestică a Regatului Maghiar (Tóth, 2009b).

Primul dicționar complet editat cu intrări ordonate alfabetic apare în 1585 la Lyon. Cartea are la bază opera lexicografului Ambrosius Calepinus, un dicționar explicativ, etimologic, avînd și explicații gramaticale asupra limbii latine. Fiind o lucrare semnificativă, acestei lucrări i-au fost adăugate echivalente în mai multe limbi. Ediția care conține și corespondente maghiare este scrisă în zece limbi: Ambrosii Calepini Dictionarivm decem Lingvarum. Lyon, 1585 Vbi Latinis Dictionibvs Hebrae, Grece, Gallice, Italice, Germanice, et Hispanice, itèmque nunc primò et Polonice, Vngarice atque Anglice adiecte sunt. Cunoaștem încă nouă ediții ale acestei variante, ultima fiind tipărită în 1627 la Basel. Autorul maghiar nu este cunoscut, s-au făcut multe presupuneri asupra eruditului sau erudiţilor maghiari, însă Melich (1912), după analiza fonetică și lexicală a materialului, este de părere că intrările maghiare cel mai probabil au fost adăugate de o singură persoană originară din Transilvania.

Pe lîngă dicționarele monumentale, cele mai populare opere lexicografice ale secolului al 16-lea erau

\footnotetext{
${ }^{13}$ Inițial, Nagy (1887), preluînd argumentele lui Szily (1886), consideră că autorul fragmentului găsit ar fi un jezuit pe nume de István Szántó (Arator) care a lucrat la dicționar între 1580 și 1584. Însă Szilágyi (1891) spune că autorul ar fi umanistul și istoricul István Szamosközy, pe numele umanist Zamosius (1570, Cluj - 1612, Alba Iulia), iar ulterior acest monument lingvistic este denumit Fragmentul lui Szamosközi (Szamosközi-szótártöredék). Dacă ne uităm la anul de naștere al istoricului transilvănean, ne putem da seama că la vremea redactării dicționarului el avea 10 ani; astfel, ori nu el este cel care a scris lucrarea lexicografică, ori acest manuscris s-a redactat mai tîrziu.

${ }^{14}$ De exemplu: „Értelmes bezedewseg: charientismos; lat. urbanitas, lepos, sermonis venustas. Értelmes: Literæ gravissimis verbis atque sententiis. Cic. 10. 16. - Literæ magna verborum sen-ten tiarumque gravitate. 10. 12. - Literæ pleni consilii, summæque cum benevolentiæ, tum etiam prudentiæ. 9. 4. Att. - Prudentes et multi officii et consilii literæ. - Literæ amantissime et honorifioentissime scriptæ. - Literæ humanitatis sparsæ sale. Cic. 1., 10. Att.” (Bartók, 2017, p. 33).

${ }^{15}$ Localitatea fiind Ojdula (jud. Covasna). Între cuvintele-titlu Epiphania și Epystola, pe margine găsim: „Anno Domini 1617 die uero 14 Mensis Augusti. Az eoz aratatast (sic!) uegeztettel el, az poliani hataron” (Melich, 1905, p. 175) (= Ai pus să are hotarul dinspre Poian).
} 
cele în cinci limbi. De obicei acestea au la bază limba latină, cum este și în cazul dicționarului lui Faustus Verancsics (Vrančić, Verantius) (1551, Šibenik ${ }^{16}$ - 1617, Veneția): Dictionarivm quinque nobilissimarum Evrope Lingvarvm, Latine, Italice, Germanice, Dalmatice et Vngarice (1595, Veneția). Avînd în vedere că în epocă erau deja în circulație numeroase lucrări lexicografice, s-a presupus că Verancsics a avut ca model mai multe dicționare pentru a-și întocmi lista cuvintelor-titlu. Víg (2011) însă constată că—deși în unele părți se pot descoperi asemănări-numărul acestora este foarte mic și probabil autorul s-a bazat pe cunoștințele proprii de limbă. Cînd a întîmpinat dificultăți, a folosit chiar și sintagme, fraze, formulări proprii, utilizînd surse ocazional, cînd a avut posibilitatea (Víg, 2011, p. 60). Însemnătatea dicţionarului este multiplă: este primul dicționar croat-maghiar ${ }^{17}$ și este prima lucrare în care sînt menționate posibilele etimologii slave ale unor cuvinte maghiare. În anexe, pe paginile 118-123, avem un Vocabula Dalmatica que Vngari sibi vsurparvnt, adică sînt prezentate 305 perechi de cuvinte asemănătoare. Pe ultimele pagini ale dicționarului autorul publică texte bisericești în cele cinci limbi. Verancsics este considerat iniţiatorul lexicografiei croate, iar din lucrarea lui s-au făcut selecții ulterioare. Astfel, în ultimii ani ai secolului al 16lea și primii ai secolului al 17-lea au apărut mai multe dicționare maghiar-latine, croat-latine și se presupune că dicționarul maghiar-italian al lui Bernardino Baldi rămas în manuscris este o selecție făcută pe baza operei lui (Víg, 2011, p. 33).

Ultima lucrare semnificativă de la sfîrșitul secolului al 16-lea este un dicționar frazeologic trilingv scris de János Baranyai Decsi (1560, Decs ${ }^{18}$ - 1601, Tîrgu-Mureș), intitulat Adagiorum Greco-LatinoUngaricorum Chiliades quinque (1598, Bártfa ${ }^{19}$ ). Ca o încercare timpurie de a găsi echivalentele maghiare ale unor proverbe, zicători latine, putem aminti niște glose de la începutul secolului al 16-lea înscrise întrun incunabulum ${ }^{20}$. O altă încercare o reprezintă glosele, proverbele maghiare scrise între 1515 și 1540 de către un canonic din Alba Iulia, Tamás Pelei, care a făcut însemnări într-o ediție venețiană din 1508 a culegerii lui Erasmus. Însă acestea sînt numai încercări de traducere (Paczolay, 2001, p. 13). Nu avem informații despre alte glose sau culegeri. Dicționarul frazeologic al lui Baranyai pare să fie fără precedent în lexicografia timpurie. În introducere, autorul enumeră sursele antice și medievale latine ale lucrării, printre care găsim numele lui Laertius, Teophrastos, Erasmus, Gilbertus Cognatus. Baranyai preia structura cea mai populară a culegerilor medievale, însă ceea ce ne spune foarte multe despre activitatea lui de lexicograf este faptul că el nu traduce proverbele, sintagmele, frazele latine și grecești, ci încearcă să găsească echivalentele din limba maghiară ${ }^{21}$. Uneori proverbul latin pare să fie traducerea frazei maghiare: „Meße Buda sánta embernek - Procul Buda claudo" (vezi și Paczolay, 2001). Astfel, dicționarul poate fi considerat una dintre cele mai valoroase lucrări lexicografice-pe lîngă argumentul adus mai sus_și prin faptul că, studiindu-l, putem avea o viziune asupra zicalelor și a proverbelor folosite în secolul al 16-lea. Din fericire, această lucrare nu a fost uitată, o parte a fost preluată de autorii altor dicționare pe care le voi aminti mai tîrziu și de autorii manualelor din secolele al 18-lea şi al 19-lea.

Albert Szenczi Molnár (1574, Szenc ${ }^{22}$ - 1634, Cluj), bazîndu-se pe cele mai bune dicționare germane și franceze, a reușit să scrie un dicționar maghiar-latin și latin-maghiar practic, ușor de folosit, comparabil cu lucrările lexicografice moderne. Ediția 1604 de la Nürnberg, Dictionarivm Vngarico-latinvm și Dictionarivm Latinoongaricum, conține în primul rînd cuvinte și expresii de uz cotidian, dar are și numeroși termeni literari, noțiuni legate de artele plastice, de politică, de științe sociale, chiar și antroponime, toponime, hidronime. Autorul face referire uneori nu numai la aspecte specifice maghiare, ci și la unele personale $^{23}$. Titlul însuși atrage atenția asupra importanței sinominelor: „Synonyma quam plurima quæ

\footnotetext{
${ }^{16}$ Azi localitate în Croația.

${ }^{17} \mathrm{De}$ fapt, a folosit cuvintele și variantele dialectului vorbit în Dalmaţia.

${ }^{18}$ Astăzi localitate în județul Tolna, Ungaria.

${ }^{19}$ Astăzi: Bardejov, Slovacia.

${ }^{20}$ Philelphus, Franciscus, Epistole, Jacobus Britannicus, Brescia, 1485.

${ }^{21}$ De exemplu: „Tota erras via Item: Toto cælo errat Oly mefzfze vagy tŏlle, mint Mako Ierufalemtŏl” (= Ești atît de departe (de ceva) ca și Makó [localitate din sudul Ungariei] de Ierusalim).

${ }^{22}$ Astăzi Senec, Slovacia.

${ }^{23}$ De exemplu, în cazul localității Szenc, precizează că acesta este orașul său natal.
} 
Emese Fazakas

inventati Vngaricæ hactenus ista commoditate destitutæ, quasi sylvam quandam vocabularum suppeditabunt", așa cum și în dicționarele moderne de multe ori specificăm sinonime în funcție de context. Pe lîngă aceste caracteristici putem găsi și mențiuni stilistice, de exemplu: „eleganter, rectius, espresse” (Szathmári, 2007, p. 166). Astfel, putem avea o viziune și asupra ariei de folosință a unor cuvinte, expresii și termeni. Ediția 1604 mai cuprinde un vocabular latin-maghiar de cinci pagini (pe două coloane) cu termenii juridici folosiți cel mai rar. În ultimele 30 de pagini sînt înşirate epitetele adjectivale folosite de Cicero ${ }^{24}$, antonimele acestora, adverbele cel mai frecvent folosite și verbele cu care acestea formează o sintagmă întrun anumit context (Szathmári, 2007, p. 167). În 1611 apare la Hanau o ediție îmbogăţită cu echivalente grecești (Lexicon latino greco hungaricum), iar în 1621 Szenczi Molnár reeditează la Heidelberg cartea, adăugînd o formă revizuită a dicționarului maghiar-latin (Lexicon Latino-graco-Ungaricum - Dictionarium Ungarico-Latinum). Această ediție-pe lîngă toate caracteristicile sus-menționate-se distinge de lucrările lexicografice contemporane prin includerea multor proverbe, zicale ${ }^{25}$, preluate mai ales din opera lui János Baranyai Decsi, și prin înșirarea variantelor dialectale ale unor cuvinte ${ }^{26}$ (Szathmári, 1999). Opera lexicografică a lui Albert Szenczi Molnár este importantă și în procesul de formare a limbii literare maghiare și în dezvoltarea lexicografiei moderne.

În 1708 apare la Lőcse ${ }^{27}$ unul dintre cele mai semnificative dicționare ale secolului: Dictionarium Manuale Latino-Ungaricum et Ungarico-Latinum. Autorul, Ferenc Pápai Páriz (1649, Dej-1716, Aiud) este filosof, poet, medic, profesor al colegiului din Aiud ${ }^{28}$, autorul a mai multe tratate medicale în limba latină și maghiară, unul dintre primii erudiți care au contribuit la dezvoltarea abordării științifice moderne. Prima parte a dicționarului (Dictionarium Manuale Latino-Ungaricum) este o lucrare originală la scrierea căreia Pápai Páriz a consultat mai multe dicționare: latin-francez, latin-englez și latin-german, pe lîngă lucrările lui Comenius și pe lîngă ediția 1646 apărută la Alba Iulia cu explicații şi echivalente maghiare a culegerii frazeologice a lui Marcus F. Wendelinus intitulată Medulla Latinitatis (Cser, 2006, p. 341). În cazul echivalentelor maghiare, mai ales în cazul denumirilor ustensilelor, a obiectelor de uz casnic și a ocupațiilor, meșteșugurilor, face distincția între formele, variantele care pot fi numite oarecum standard ${ }^{29}$ și cuvintele, variantele dialectale. De asemenea, Pápai Páriz marchează cuvintele dispărute din limba vorbită prin mențiunea: antique. A doua parte a dicționarului este o ediție îmbogățită a lucrării lui Szenczi Molnár, aşa cum se precizează și în titlu: Dictionarium Hungarico-Latinum, olim magnâ curâ à Clarissimo viro Alberto Molnár Szentziensi collectum; Nunc vero revisum, \& aliquot vocabulorum, in Molnariano desideratorum, millibus Latinè redditis locupletatum. Ediția a doua, din 1762 apărută la Nagyszombat ${ }^{30}$, are o anexă frazeologică contrastivă (Cser, 2006, p. 341).

Dintre edițiile ulterioare, cea din 1767 este importantă. Această ediție este pregătită de către Péter Bod (1712, Cernatu de Sus - 1769, Ighiu). Bod-inspirîndu-se din lucrarea lui Szenczi Molnár-scrie o prefață, în care descrie cele mai importante dicționare apărute și folosite pînă la jumătatea secolului al 18-lea. Așa cum este precizat și în titlu (Dictionarium latino-bungaricum, succum et medullam purioris Latinitatis, ejusque genuinam in Ligvam Hungaricam conversionem... Francisco Páriz Pápai... Nunc vero proverbiis selectioribus interspersis, glossariolo voces Medii et Nostri avi, in Historiis, et Regnum Hungarie Decretis occurantes, insolentiores etc., explicante, Nominibus Propriis apud Hungaros usitatis, Nummorum Hungaricorum, Hebraicorum, Gracorum, Romanorum Tabellis, Siglarum Romanarum Expositione, aliisque necessariis et jucundis Accessionibus locupletatum intentione ac labore Petri Bod de F. Tsernáton,

\footnotetext{
${ }^{24}$ Eitheta, Antitheta et Adiuncta ex M. T. Ciceronis Collecta.

${ }^{25}$ Chiar și în titlul lucrării atrage atenția asupra proverbelor: „qui inspersa sunt usitatiora proverbia ungarica”.

${ }^{26}$ De exemplu: „Leány - Lyán, Elvonom - Elvonyom; pro Schola dicant indifferenter Eskola, Iskola, Oskola” (Szathmári, 1999).

${ }^{27}$ Astăzi Levoča, Slovacia.

${ }^{28}$ Vezi fragmentul din titlul dicționarului (ediția 1767): „Francisco Páriz Pápai Medicinae Doctore, Ejusdemque Facultatis in Celeberrima Academia Basileensi, Assessore; \& in Illustri Collegio Nagy-Enyediensi Professore Publico".

${ }^{29}$ Deși nu putem încă vorbi de o limbă standard, de un secol se pot distinge deja lexemele în curs de standardizare de cele dialectale.

${ }^{30}$ Astăzi Trnava, Slovacia.
} 
V.D. Ministri M. Igeniensis), prima parte are ca anexe un vocabular al numelor proprii latine folosite în Ungaria, o listă a abrevierilor latine $e^{31}$ și mai multe tabele cu conversia măsurilor și monedelor ${ }^{32}$. Partea a doua (Dictionarium hungarico-latinum, Olim magna cura a clarissimo viro Alberto Molnar Szentziensi collectum; Tandem Revisum et aliquot vocabulorum, in Molnariano desideratorum, millibus Latiné redditis locupletatum, Studio et vigiliis Francisci Páriz Pápai... Nunc vero Tam ex ejusdem Philoponi F. P. Pápai secundis curis ac Notationibus Mss. quam propriis et aliorum Observationibus, expletis que defuerunt, amputatis que superfuerunt, et vocibus quibusvis in suum ordinem redactis, volentiam usibus editum; Opera Petri Bod de F. Tsernáton, V. D. Ministri M. Igeniensis. Nove huic Editioni nunc primum solertia Typographi addita est Lingva Germanica) este îmbogățită de către Bod cu echivalente germane. Péter Bod a cerut ajutorul lui József Benkő (1740, Brăduț - 1814, Aita Medie), care atunci era elev la Aiud, și o parte a cuvintelor adunate de Benkő au fost publicate cu echivalentele lor în latină și germană în Addenda dicționarului. Această anexă se întinde pe doar două pagini, însă semnificația listei este mult mai mare deoarece Benkő include cuvinte folosite în dialectele din Secuime și cuvinte provenite din limba română (de exemplu: armás 'armaș, bálmos 'balmoș, kaláka 'clacă', kompona 'cumpănă'). Semnificația acestei liste constă în faptul că aceste cuvinte apar pentru prima dată într-un dicționar maghiar-latin(-german), iar multe dintre ele sînt pentru prima dată menționate în scris (Éder, 1978, p. 40-45).

József Benkő continuă să culeagă elemente din lexicul transilvănean și este interesat mai ales de termeni botanici. Astfel, în 1783 publică două dicționare la Pozsony (Bratislava): primul, Nomenclatura Botanica, este un dicționar latin-maghiar-german-francez prelucrat după sistemul botanic al lui Linné, iar al doilea, Nomina Vegetabilium, este un dicționar latin-maghiar-român. János Molnár, în prefața scrisă la Nomina Vegetabilium — bazîndu-se pe scrisorile lui Benkő—, relatează de ce autorul a considerat necesar să includă denumirile românești ale plantelor: românii sînt cunoscători ai plantelor medicinale și le folosesc cu mai multă iscusință decît celelalte popoare. De asemenea, el face referire la un doctor român care, după ce a practicat la București, s-a mutat la Brașov și care i-a fost de mare ajutor în redactarea dicţionarului, ca de altfel și patru farmacişti saşi din Cluj și din Braşov ${ }^{33}$. Aceste lucrări sînt remarcabile nu numai în ansamblul operei lui József Benkő, dar reprezintă şi o etapă importantă în dezvoltarea lexicului botanic maghiar și au avut o mare influență asupra literaturii și lexicografiei botanice săsești și românești din Transilvania (Éder, 1978, p. 33). Se cunosc trei culegeri, dicționare care s-au scris pe baza lucrărilor lui Benkő: P. Sigerus Verzeichniss der Offizinellet Pflanzen (Siebenbürgische Quartalschrift, 1797); M. Fuss Verzeichniss der Pflanzen und der wichtigsten Synonymen (Archiv des Vereins für Sieb. Vaterlandsk, Hermanstadt 1846, III. 349-395); M. Fuss Alfabetische Zusammenstellung der ungarischen, wallachischen und deutschen Trivialnamen (Archiv des Vereins für Sieb. Vaterlandsk. Hermanstadt 1847, III. 177208). Însă mult mai importantă este influența operei lui asupra lexicografiei și terminologiei românești, deoarece Nomina Vegetabilium este considerată prima lucrare lexicografică românească tipărită (Kelemen, 1957, p. 34). Această lucrare a fost folosită și de autorii dicționarelor Dictionarium Valachico-Latinum (1806, Buda) și Lexicon Budensis (1825, Buda). Din păcate, nici lexicografii, nici botanicii maghiari nu au apreciat la vremea lor munca lui József Benkő (Éder, 1978, p. 33).

\footnotetext{
${ }^{31}$ „Characterum Romanorum atque Siglarum Expositio, faciens pro Lapidum, Monetarum Inscriptionibus interpretandis, ex variis Auctoribus collecta; Notæ Juris a Magone Collectæ; Signaturæ Philosophorum”.

${ }^{32}$ „Tabella nummorum hungaricorum; Tabella nummorum hebraicorum; Pecunia græcorum hungaricis comparata; Tabella nummorum græcorum; Signati romanorum nummi; Tabella pecuniæ romanæ; Ratio supputandi per sestertios”.

${ }^{33}$ „A' Tudosításban az Iró, kinek ditséretes más illy munkája az első Szakafzban találtatik, elé-adja igyekezetének okát: mert az Oláhság igen isméri a' füveket, 's azokat hafzonra fordítván, más nemzeteket fellül halad. E' nevek özve-fzedésében fegitöje vólt Molnár Adány nevezetes Orvos Doktor; ki Brassóban végzé életét 1780-ban; minekutána majd 20. efztendeig vifelte az Orvosi hivatalt Bukereftben Havás al-földön (...) Egyéb fegittöje (...) Mauks Tobiás Kolozsvári nagy nevü Patikárius Úr, Weifskircher, Langedorf, és Birk Brassói Patikáros Urak (...) Tétettek ide olly Magyar fzózatok-is mellyek az elébbenyi munkában el-hagyattak" (vezi Éder, 1978, p. 32-33).
} 


\section{Concluzii}

Prezentarea începuturilor lexicografiei maghiare nu a avut ca scop enumerarea tuturor lucrărilor lexicografice, care chiar și pînă în secolul al 16-lea sînt numeroase, ci doar indicarea celor mai importante glose, vocabulare, nomenclaturi, dicționare bi- și multilingve. Astfel, am prezentat glose timpurii, marginale sau interliniare începînd din secolul al 13-lea. Una dintre cele mai importante surse lingvistice timpurii în care glosele sînt intertextuale, distinse de textul latin prin subliniere, sînt incluse în Sermones Dominicales, o compilație de predici scrise în prima parte a secolului al 15-lea. Vocabularele și nomenclaturile discutate sînt redactate între secolul al 14-lea și sfîrșitul secolului al 16-lea, majoritatea avînd la bază o listă de cuvinte latine grupate în cîmpuri semantice. Singura lucrare care s-a redactat pornind de la lexicul maghiar este Nomenclatura din Schlägl, o copie făcută în jurul anului 1405 după un document întocmit cu cîteva decenii mai devreme. Printre aceste vocabulare se găsesc și cîteva care pot fi considerate primele încercări de redactare a unor dicționare de specialitate, cum ar fi vocabularul botanic scris în jurul anului 1526, nomenclatura lui Balázs Szikszai Fabricius, editată în 1590, și primul vocabular juridic latin-maghiar din 1611. Nomenclatura lui Szikszai Fabricius este prima care a avut un impact asupra lucrărilor ulterioare, asupra dezvoltării lexicografiei săsești din Transilvania. Începînd cu secolul al 16-lea, există mai multe dicționare ale căror cuvinte-titlu sînt aranjate alfabetic, însă cele timpurii au rămas nefinalizate sau nu s-au păstrat în intregime. Cele mai reprezentative dicționare se scriu începînd cu sfîrșitul secolului al 16lea, majoritatea fiind multilingve și cunoscînd mai multe ediții. Printre acestea, dicționarul lui Faustus Verancsics marchează începuturile lexicografiei croate și ale dicţionarelor etimologice maghiare. Dicționarul frazeologic trilingv al lui János Baranyai Decsi se remarcă prin echivalentele și nu prin traducerile maghiare ale proverbelor latine și grecești, iar materialul este folosit de Albert Szenczi Molnár și de Péter Bod în secolele următoare. Primul dicționar maghiar-latin și latin-maghiar practic, ușor de folosit și care conține și nume proprii este redactat de Albert Szenczi Molnár (1604), iar una dintre cele mai importante lucrări o reprezintă ediția completată și rescrisă de către Péter Bod (1769) a dicționarului lui Ferenc Pápai Páriz (1708). Aceasta este cea mai folosită lucrare lexicografică timp de mai multe decenii. Prezentarea se încheie cu dicționarele botanice ale lui József Benkő editate în 1783, care marchează începutul lexicografiei moderne maghiare și care a contribuit și la dezvoltarea lexicografiei românești și săsești.

\section{Bibliografie}

Bartók, I. (2017). „Patvaros philosophusok, visszalkodo, maguk hanio böltsek”. Adalékok az 1530-1580 között keletkezett magyarországi glosszák, szójegyzékek és szótártöredékek kritikatörténeti vonatkozásaihoz, în „Irodalomtörténeti Közlemények”, 121, p. $23-60$.

Benkő, L. (1958). A Marosvásárhelyi Sorok és Glosszák, în „Magyar Nyelv”, 54, p. 17-22.

Benkő, L. (1984). Megjegyzések az „Oxfordi glosszák” szavaihoz, în „Magyar Nyelv”, 80, p. 74-75.

Büky, B. (1984). Az „Oxfordi glosszák” szavairól, în „Magyar Nyelv”, 80, p. 71-73.

Cser, A. (2006). A magyar nyelvtudomány történetének áttekintése a kezdetektöl a 20. század elejéig, în Bajor, P., Kiefer, F., NáraySzabó, G. \& Pál, J. (eds), A magyar nyelv, Akadémiai Kiadó, Budapest, p. 335-351.

Éder, Z. (1978). Benkő József nyelvészeti munkássága és az Erdélyi Magyar Nyelvmüvelö Társaság, Akadémiai Kiadó, Budapest. Ernyey, J. \& Jakubovich, E. (1915). Két természetrajzi szójegyzék. I. „Ortus sanitatis”, în „Magyar Nyelv”, 11, p. 37-39, 80-83. Farczády, E. \& Szabó T., A. (1957). A Marosvásárhelyi Sorok, Editura Academiei, București.

Fejér, R. (1995). Zur Geschichte der deutsch-ungarischen und ungarisch-deutschen Lexikographie. Von der Jahrhundertwende bis zum Ende des Zweiten Weltkrieges, Max Niemeyer Verlag, Tübingen.

Finály, H. (1892). A Besztercei Szószedet. Latin-magyar nyelvemlék a XV. századból, Értekezések a Nyelv- és Széptudomány Köréből XVI., Magyar Tudományos Akadémia, Budapest.

Gábriel, A. (1943). Egy XIII. századi magyar diák Párizsban, în „Egyetemes Philologiai Közlöny”, 67, p. 164-195.

Gáldi, L. (1938). Contributions à l'étude des lexiques latins-hongrois du moyen âge, Eötvös-füzetek XI, Eötvös Collegium volt Tagjainak Szövetsége, Budapest.

Gl. = Berrár, J. \& Károly, S. (eds) (1984). Régi magyar glosszárium. Szótárak, szójegyzékek és glosszák egyesitett szótára, Akadémiai Kiadó, Budapest.

Gombocz, E. (1936). A magyar botanika története, Magyar Tudományos Akadémia, Budapest. 
Kelemen, B. (1957). Az új román-magyar nagyszótár szerkesztésének legfontosabb elvi és gyakorlati szempontjai, în „Nyelv- és Irodalomtudományi Közlemények", 1, p. 33-49.

Kertész, B. (2009). Magyi János formuláskönyve, în Madas, E. (ed.), „Latiatuc feleym...”. Magyar nyelvemlékek a kezdetektöl a 16. század elejéig. Az Országos Széchényi Könyvtár kiállitása 2009. október 29-2010. február 21, Országos Széchényi Könyvtár, Budapest, p. 248-249.

Madas, E. (2009). Gyulafehérvári Sorok, în Madas, E. (ed.), „Latiatuc feleym...”. Magyar nyelvemlékek a kezdetektöl a 16. század elejéig. Az Országos Széchényi Könyvtár kiállitása 2009. október 29-2010. február 21, Országos Széchényi Könyvtár, Budapest, p. 228-229.

Melich, J. (1898). A gyöngyösi latin-magyar szótár-töredék, Magyar Tudományos Akadémia, Budapest.

Melich, J. (1905). A brassói latin-magyar szótár-töredék, Értekezések a Nyelv- és Széptudomány Köréből 19/4, Magyar Tudományos Akadémia, Budapest.

Melich, J. (1906). Szikszai Fabricius szójegyzéke 1590-ből, Magyar Tudományos Akadémia, Budapest.

Melich, J. (1907). A magyar szótárirodalom, Athenæum Irod. és Nyomdai Részvénytársulat, Budapest.

Melich, J. (1912). Calepinus latin-magyar szótára 1585-böl, Magyar Tudományos Akadémia, Budapest.

Melich, J. (1916). A Königsbergi Szójegyzék, în „Magyar Nyelv”, 12, p. 145-149, 263-265.

Mészöly, G. (1910). Jegyzetek a „Sermones dominicales” szótárához, în „Magyar Nyelv”, 6, p. 401-406.

Mezey, L. (1979). Deákság és Európa. Irodalmi müveltségünk alapvetésének vázlata, Akadémiai Kiadó, Budapest.

Mezey. L. (1981). Az Oxfordi Glosszák, în „Magyar Nyelv”, 77, p. 372-376.

Nagy, Gy. (1887). Egy kéziratban maradt magyar-latin szótártöredék 1580 tájáról, în „Magyar Könyvszemle”, 12, p. $100-110$.

Paczolay, Gy. (2001). Baranyai Decsi Csimor János, a szóláskutató, în „Erdélyi Múzeum”, 3-4, p. 12-27.

Pálfi, M. (1907). Kolozsvári Glosszák, Nyelvészeti Füzetek 45. Athenæum Irodalmi és Nyomdai R. T., Budapest.

Péter, K. (2012). Werböczy anyanyelvi forditásainak tanulságai - értelmiségi feladatvállalás a 16. században, în „Történelmi Szemle”, 3, p. 421-440.

Schönherr, Gy. (1904). A római Casanate-könyvtár Korvin-kódexe, în „Magyar Könyvszemle”, 29, p. 435-469.

Szabó T., A. (1943). Magyar növény-és gyógyszernevek a XVI. századból, în „Magyar Nyelv”, 39, p. 331-333, 391-397.

Szabó T., A. (1957). A Marosvásárbelyi Sorok és Glosszák, în „Magyar Nyelv”, 53, p. 335-351.

Szabó T., A. (1958). Magyar növény- és gyógyszernevek a XVI-XVIII. századból, în „Studia Universitatum Victor Babeș et Bolyai", III (6), series IV., fasc. 1, p. 161-177.

Szamota, I. (1894). A Schlägli magyar szójegyzék a XV. század elsö nyegyedéböl, Akadémiai Kiadó, Budapest.

Szamota, I. (1896). A Murmelius-féle latin-magyar szójegyzék 1533-ból, Értekezések a Nyelv- és Széptudományok Köréből, Magyar Tudományos Akadémia, Budapest.

Szathmári, I. (1999). Személy-és folldrajzi nevek Szenczi Molnár Albert 1621-i magyar-latin szótárában, în „Névtani Értesíto”, 21, p. 270-274.

Szathmári, I. (2007). Mennyiben szolgálták Szenczi Molnár Albert szótárai a magyar irodalmi nyelv (sztenderd) létrejöttét?, în „Magyar Nyelvőr”, 31, p. 163-172.

Szilágyi, S. (1891). Szamosközy István szótára, în „Magyar Könyvszemle”, 16, p. 100-110.

Szily, K. (1886). Ki volt Calepinus magyar tolmácsa?, Értekezések a Nyelv- és Széptudományok Köréből, Magyar Tudományos Akadémia, Budapest.

Tóth, P. (2009a). Sermones Dominicales, în Madas, E. (ed.), „Latiatuc feleym...”. Magyar nyelvemlékek a kezdetektöl a 16. század elejéig. Az Országos Széchényi Könyvtár kiállitása 2009. október 29-2010. február 21, Országos Széchényi Könyvtár, Budapest, p. 244-245.

Tóth, P. (2009b). Schlägli Hortularium, în Madas, E. (ed.), „Latiatuc feleym...”. Magyar nyelvemlékek a kezdetektöl a 16. század elejéig. Az Országos Széchényi Könyvtár kiállitása 2009. október 29-2010. február 21, Országos Széchényi Könyvtár, Budapest, p. 238-239.

Varjú, E. (1899). A gyulafejérvári kódex, în „Akadémiai Értesítő”, 10, p. 16-25.

Víg, I. (2011). Verancsics Faustus Dictionariuma a korabeli európai kontextusban, Tinta Kiadó, Budapest.

Viski, K. (1905). Nyelvemlék a kolozsvári református kollégium könyvtárában, în „Magyar Nyelvő”, 34, p. 200-2003.

Viski, K. (1906). Tordai Tamás lapszéli jegyzetei a XVI. századból, în „Magyar Nyelvőr”, 35, p. 222-224.

Vízkelety, A. (2009). Irodalmak útban a pergamen felé, în Madas, E. (ed.), „Latiatucfeleym...”. Magyar nyelvemlékek a kezdetektöl a 16. század elejéig. Az Országos Széchényi Könyvtár kiállitása 2009. október 29-2010. február 21, Országos Széchényi Könyvtár, Budapest, p. 79-93.

Zelliger, E. (2009). Schlägli szójegyzék, în Madas, E. (ed.), „Latiatuc feleym...”. Magyar nyelvemlékek a kezdetektöl a 16. század elejéig. Az Országos Széchényi Könyvtár kiállitása 2009. október 29-2010. február 21, Országos Széchényi Könyvtár, Budapest, p. 237.

Zolnai, Gy. (1910). A Budapesti és Németújvári Glosszák, în „Magyar Nyelvőr”, 19, p. 460-474. 